\title{
Tax as a therapeutic target in ATL
}

\author{
Zeina Dassouki ${ }^{1,2^{*}}$, Umut Sahin 2,3,4, Hiba El Hajj ${ }^{1}$, Florence Jollivet ${ }^{2,3,4}$, Youmna Kfoury ${ }^{1}$, \\ Valérie Lallemand-Breitenbach ${ }^{2,3,4}$, Olivier Hermine ${ }^{7}$, Hugues de The ${ }^{2,3,4,5,6}$, Ali Bazarbachi ${ }^{1}$ \\ From 17th International Conference on Human Retroviruses: HTLV and Related Viruses \\ Trois Ilets, Martinique. 18-21 June 2015
}

The HTLV-1 Tax transactivator initiates transformation in adult T-cell leukemia/lymphoma (ATL), a highly aggressive chemotherapy-resistant malignancy. The arsenic/interferon combination, which triggers degradation of the Tax oncoprotein, selectively induces apoptosis of ATL cell lines and has significant clinical activity in Tax-driven murine ATL or patients. Yet, the role of Tax expression in maintaining the transformed phenotype and of Tax loss in ATL response is disputed and the molecular mechanisms driving degradation remain elusive. Here we demonstrate that ATL-derived or HTLV-1 transformed cells are addicted to continuous Tax expression, suggesting that Tax degradation underlies clinical responses to the arsenic/interferon combination. The latter enforces PML nuclear body (NB) formation and partner protein recruitment. In arsenic/ interferon-treated ATL-derived cells, Tax is recruited onto NBs, undergoes PML-dependent hyper-sumoylation by SUMO2/3, but not SUMO1, ubiquitination by RNF4 and proteasome-dependent degradation. Thus, the arsenic/interferon combination clears ATL through degradation of its Tax driver and could have broader therapeutic value by promoting degradation of other pathogenic sumoylated proteins.
Published: 28 August 2015

doi:10.1186/1742-4690-12-S1-P57

Cite this article as: Dassouki et al:: Tax as a therapeutic target in ATL. Retrovirology 2015 12(Suppl 1):P57.

\begin{abstract}
Authors' details
'Department of Internal Medicine, Faculty of Medicine, American University of Beirut, Beirut, Lebanon. ${ }^{2}$ Université Paris Diderot, Sorbonne Paris Cité, Hôpital St. Louis 1, Avenue Claude Vellefaux 75475 Paris, Cedex 10, France. ${ }^{3}$ INSERM UMR 944, Equipe labellisée par la Ligue Nationale contre le Cancer, Institut Universitaire d'Hématologie, Hôpital St. Louis 1, Avenue Claude Vellefaux 75475 Paris, cedex 10, France. ${ }^{4}$ CNRS UMR 7212, Hôpital St. Louis 1 , Avenue Claude Vellefaux 75475 Paris, cedex 10, France. ${ }^{5}$ AP-HP, Service de Biochimie, Hôpital St. Louis 1, Avenue Claude Vellefaux 75475 Paris, cedex 10, France. ${ }^{6}$ College de France, Place Marcelin Berthelot 755 Paris, France. ${ }^{7}$ CNRS UMR 8147, Hôpital Necker, Paris, cedex 15, France.
\end{abstract}

'Department of Internal Medicine, Faculty of Medicine, American University of Beirut, Beirut, Lebanon

Full list of author information is available at the end of the article
Submit your next manuscript to BioMed Central and take full advantage of:

- Convenient online submission

- Thorough peer review

- No space constraints or color figure charges

- Immediate publication on acceptance

- Inclusion in PubMed, CAS, Scopus and Google Scholar

- Research which is freely available for redistribution

\section{() Biomed Central}

C Biomed Central

C 2015 Dassouki et al. This is an Open Access article distributed under the terms of the Creative Commons Attribution License (http:// creativecommons.org/licenses/by/4.0), which permits unrestricted use, distribution, and reproduction in any medium, provided the original work is properly cited. The Creative Commons Public Domain Dedication waiver (http://creativecommons.org/publicdomain/ zero/1.0/) applies to the data made available in this article, unless otherwise stated. 